\title{
The discussing on teaching reform of "Data structure" course in application-oriented universities
}

\author{
Ding Linhua ${ }^{1, a}$ \\ ${ }^{1}$ School of Informatics, LinYi University, Linyi 276000, China \\ aemail:private_ding@163.com
}

Keywords: Application-oriented universities; data structure; teaching reform; practical teaching

\begin{abstract}
Applied talents training is the need of the country, and local colleges and universities should actively promote teaching reform for the need of applied talents training. As the core of the computer professional foundation course, data structure course should adjust the teaching contents, reform the practice teaching, in order to training applied programing talents with high quality of practical ability and innovative ability.
\end{abstract}

\section{Introduction}

Training applied talents with high quality of strong social adaptation ability and competition ability have become the focus of the development for applied local undergraduate colleges and universities. Many colleges and universities began to explore applied talents cultivation and actively promote the teaching reform combining with local characteristics, in order to better serve the national development[1]. In the process of applied characteristic school construction of LinYi university, School of Informatics are also actively promote the reform of teaching to explore the applied talents training mode.

"Data structure" is the core basic course for computer professional students, so it is to be included in computer science professional courses in almost all of the colleges and universities. The research content of this course is numerical and structural data, and it is the basis of the general program design[2][3]. For students to be engaged in software development and design in future, data structure is a very important theoretical basis. But its strong theoretical lead to the students' interest in learning is not high, so as to difficult to really realize the importance of data structure in the actual program design and software development.

Combining with teaching practice of "data structure" course for many years in School of Informatics, LinYi University. This paper sums up teaching problems of "data structure" course in current applied local undergraduate colleges and universities, and puts forward the teaching reform direction and methods suitable for their own development and orientation.

\section{Teaching Problems of "Data Structure" Course in Applied Undergraduate}

"Data structure" is the core foundation course for computer professional students. Through the study of this course, it will make the student thoroughly to understand the characteristics of all kinds of data objects, data organization method and realization method, so as to further develop the students' computing thinking and good program design ability[2][3]. At present in most of the applied undergraduate colleges, teaching of data structure did not meet the requirement of applied talents training mode, leading to quite a number of students generally do not feel what role does the data structure, more can't put this to use.

Firstly, training objectives are not clear, and the teaching content heavy theory, light applications. The students' average level of computing thinking ability and program design ability is not high in local applied colleges and universities. Teaching contents of data structure focuses on theoretical knowledge, including the basic logical relationship of data structure, storage structure and algorithm implementation. These knowledge are strong theoretical, and lack of practical application scenarios, so students are difficult to complete transformation from theory to application, more can't finish 
data analysis, data organization and corresponding algorithm design using the fundamental theory of data structure knowledge when they meet with the actual problems.

Secondly, the practice teaching system is single, and practice content is not according to their aptitude. Data structure course should focus on cultivating students' practical application ability of software design and development in order to solve actual problems using the basic types of data structure. However, because practice class proportion of data structure is too small, and the experiment content is single, it is hard to cultivate students' practice ability and innovation ability. In addition, when the data structure course begins, the students have studied a programming language or two. Though few opportunities for practice, the program design ability of students has been uneven, so the same practice content and single practice platform are difficult to meet the needs of different levels of students.

Thirdly, teaching process of data structure is given priority to professional skills, ignoring the cultivation of applied talents' comprehensive quality. Applied undergraduate talents should be the high-quality harmonious talents, not only to have certain theoretical knowledge and operating practice ability, innovation ability and other professional quality, but also have certain non-technical comprehensive qualities, such as team cooperation ability. But in the current applied undergraduate colleges and universities, the teaching contents and practice contents of data structure more is to exercise the student individual expertise, rarely pay attention to the cultivation of comprehensive quality.

\section{The Exploration of Teaching Reform of "Data Structure" Course in Applied Undergraduate}

According to the development localization of the school and students practical ability, the course group has put forward the reform ideas and methods on data structure course, and have achieved good results in practical teaching. Specific measures are as follows.

Firstly, the teaching content of "data structure" was reformed oriented by applied undergraduate education target. On the one hand, through breaking the professional limitation, the teaching contents were established combined with the students practical ability and application needs. As a practical local undergraduate colleges and universities, the level difference of students is very big in LinYi University, and their future planning are different. For example, some students want to direct employment through four years of training, others want to further study. If not considering the practical ability and application requirements of students, the same teaching materials and teaching contents are hard to meet the needs of different students. In order to really starting from the demand of students, the teaching of data structure broke traditional teaching model, according to the level of students and education planning, established two the training mode including research talents and applied talents, and established the corresponding teaching contents.For research talents who will go farther study, they need to firmly grasp the theoretical knowledge of data structure, including linear list, stack and queue, tree, graph, search and sort and their listed storage, linked storage and related operation algorithm implementation, etc.So on the premise of not reducing practice class, theoretical classes should be sufficient. For applied talents, teachers adjust teaching contents according to the actual situation of the students. For example, the teaching material of data structure course is the $\mathrm{C}$ language version. Students' degree of mastering and applying $\mathrm{C}$ language directly affects the teaching effect of data structure course. Therefore, in the beginning of teaching data structure, we firstly try to know about the students' programming ability. If it is found that the students' understanding about the core contents of $\mathrm{C}$ language, such as function, pointer and structure, is bad, then adjust the teaching content. First using several theoretical classes and experimental classes to help students understand and grasp above important and difficult knowledge, then can enter into teaching the basic content of data structure.

On the other hand, we reformed the teaching method, using comparison and case teaching mode, guided students to think from different angles on the same problem, in order to find out a variety of methods to solve it. For example, the problem of Joseph ring can be solved by a circular linked list structure, or by the serial linear table structure. This teaching methods finding different algorithm implementation on the same issue effectively broaden the thinking of students, at the 
same time by comparing different algorithms, deepen the students to deeply understand the algorithm. In the process of teaching, use more cases with high applicability interesting to introduce the teaching content. Such as using snake game introduces the structure of the linked list, when interpreting the shortest path of the figure, an interesting artificial intelligence problem - crossing the river can be as a case. The teaching method through cases guide students, makes students more intuitive understanding the practical application of data structure, so as to stimulate students' interest in learning, improve the teaching effect. Finally, we have reformed teaching method using the dual mode of classroom teaching and network teaching. Our data structure course has been rated as the provincial excellent courses, established a high-quality good curriculum website, and constantly updated to enrich the teaching resources. These have increased students' extracurricular autonomous learning, broaden the student's field of vision, and improved the students' interest in learning.

Secondly, using the progressive type of practice contents and forms reformed the practice teaching. The programing design ability of students has been a big gap, so the practice teaching content should not be a single form, should organize flexible and varied forms of practice according to the level of the students[4][5]. First of all, all of students must complete the following basic experiments such as Table1. Secondly, those students with good programming ability will be absorbed to teachers' scientific research teams, to provide practice opportunities for students relying on the teachers' scientific research projects. In additions, much cooperation with the software design companies or enterprises provides practical training platforms for students with high level programing ability. Let the students stand in the angle of the customer needs to understand the role of data structures in software development and requirements, as a way to expand students' vision, strengthen students' ability of applying professional knowledge.

Table.1. the basic and comprehensive experiments of data structure course

\begin{tabular}{c|c} 
basic experiments & Comprehensive experiments \\
\hline Foundation of C language & Parking lot management \\
\hline $\begin{array}{c}\text { Operations of the serial linear table } \\
\text { structure }\end{array}$ & Shortest path query of navigation \\
\hline Joseph ring & Phone number query \\
\hline Operations of binary tree & Jigsaw puzzle game \\
\hline Graph traversal & Air passenger booking system \\
\hline Binary sorting tree & $\begin{array}{c}\text { Tourism information management } \\
\text { system }\end{array}$
\end{tabular}

Thirdly, integrating "data structure" course with many types of programing and algorithm design competition, to cultivate the students' comprehensive quality. In order to arouse the students' interest in learning and improve the ability of students, many students took part in various forms of competition, such as QiLu Software Design Contest of ShangDong province, National LanQiao Cup Contest, ACM-ICPC Contest and other contests related to software design. Many good results have achieved for nearly four years such as Fig 1. 


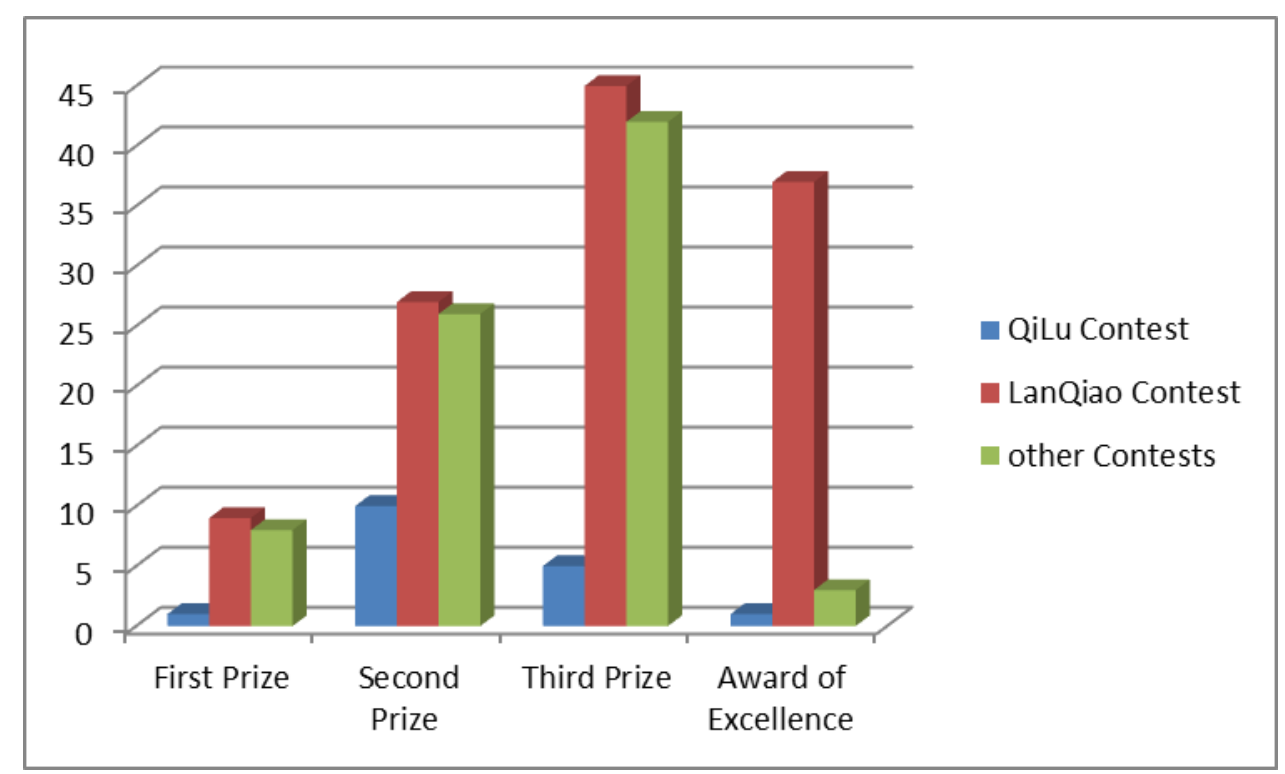

Fig.1. Awards statistics

In the process of organizing students participating above contests, the teachers have integrated the content between the contests and "data structure" course, actively introduced the content of contests related to the data structure course into the teaching process, to enrich the teaching content of data structure course[6][7]. Through carefully analysis and redesign on the content of contests in calendar years, the teachers have introduced them to the process of practice teaching of data structure course. Through training and organizing students to participate those contests, adopting competition training mode to promote teaching, that has improved the students' application and capacity for independent innovation, cultivated the students' team spirit at the same time. As the teaching content and practice content of data structure course constantly enrich, the teaching effect has obviously ascension, and the winning number of students significantly increased. For example, in LanQiao Cup Contest, the total number of the prizes is 118 for nearly four years, but the number is 83 only in 2014.

\section{Conclusion}

Cultivating applied talents is the need of national construction, local colleges and universities should actively push forward teaching reform based on the regional economic characteristics, to cultivate applied talents with high quality service for the regional economic construction. As a course training the student's ability of compute thinking and programing design, data structure course should keep up with the pace of teaching reform, update teaching ideas, reform the teaching contents, emphasis on practice teaching, to improve the students' ability of programing design, so that the students can put them to use, and become the applied talents with high comprehensive quality.

\section{Acknowledgement}

In this paper, the research was sponsored by the Excellent Course Project of Colleges and Universities in ShanDong Province (Project No. 2013BK110).

\section{References}

[1] SUN Jiang, HUANG Feng-li, HU Hong-sheng. Reform and Exploration of Practical for Training Engineering Ability of University Students[J]. Education Theory and Practice ,2014,34 (12) :42-44.

[2] ZHOU Hai-yan, CHEN Hong-ming, YIN Lu. Reflection on Teaching of "Data Structure" Course[J]. Education Theory and Practice,2010,30(6):62-63. 
[3] LI Yue-jun, LI Juan, LI Ying-yu. Research on Teaching and Teaching Material of Data Sructure Course[J]. China University Teaching, 2013,2:86:90.

[4] WANG Shu-zhang, CHEN Yong-li. College Students' Research in Higher Vocational Colleges[J]. Theory and Practice of Education,2015,35(6):20-21.

[5] LIU Yue-chang, ZHONG Xiu-yun, ZHONG Zhi-chun. Etc. Engineering Experimental Teaching of Data Structure[J]. Reserch and Exploration in Laboratory,2012,31(8):339-341.

[6] ZHAO Long, LI Bei-bei,WANG Xi-feng. The Function of ACM/ICPC Contests in the Cultivation of Students' Comprehensive Ability[J]. Reserch and Exploration in Laboratory,2013,30(3):110-111.

[7] WAGN Wei-jia, ZHANG Hong-ping, NING Ya-hui. etc. Discussion on the combination of data structure course and ACM international collegiate programming contest[J]. Computer Engineering and Science,2014,36 (A1) :257-260. 